\begin{tabular}{|c|c|}
\hline \multirow[t]{3}{*}{ ISSN 1407-7493 } & $\begin{array}{c}\text { DATORZINĀTNE } \\
\text { COMPUTER SCIENCE }\end{array}$ \\
\hline & $\begin{array}{c}\text { INFORMATION TECHNOLOGY AND } \\
\text { MANAGEMENT SCIENCE }\end{array}$ \\
\hline & $\begin{array}{c}\text { INFORMĀCIJAS TEHNOLOGGJA UN } \\
\text { VADĪBAS ZINĀTNE }\end{array}$ \\
\hline
\end{tabular}

2009-7493

\title{
THE BASELINE CONFIGURATION OF PROJECT MANAGEMENT INFORMATION SYSTEM
}

\section{PROJEKTU VADĪBAS INFORMĀCIJAS SISTĒMAS KONFIGURĀCIJAS BĀZLĪNIJA}

Solvita Bērziša is Ph.D. student of Riga Technical University management information technology program, Latvia. She has a BSc (2005) and MSc (2007) in computer science and information technology in Riga Technical University. Her research areas are IT project management, project management information systems and it configuration.

She current works in Exigen Services Latvia as system analyst - programmer. 


\begin{abstract}
The purpose of project management information systems is to facilitate development and management of projects as well as to provide operational project information. Project management information systems need to be configured according to project management requirements during their deployment. In order to reduce complexity of this task, a baseline configuration can be used as a starting point of the configuration process. The objective of this paper is to establish the baseline configuration of the project management information system. The baseline configuration is developed according a set of typical project management requirements

These requirements are determined by summarizing several project management methodologies and investigations on evaluation of project management information systems. They are divided in 15 groups. A high level description of the baseline configuration of project management information system is defined on the basis of these requirements. It consists of the list of typical project management scenarios and workflows as well as the list of relevant concepts, their default values and business rules. The baseline configuration is compared with configurations used in selected project management information systems. The obtained results further will be used in the configuration process of project management information systems.
\end{abstract}

\section{Introduction}

Project management (PM) is a complex process involving various project related activities: planning, monitoring, control and others. Projects are most often used in information technology (IT), software development, business process reorganisation and research and development [1, 2]. PM software and other related software are frequently used to support PM [1, 3]. The usage of Project Management Information Systems (PMIS) allows increasing the project success by $75 \%$ [4]. Hence quality and use of PMIS are very important [4].

One of the key problems is selection and configuration of appropriate project management software tools (PMIS is built on the basis of a selected software tool). The selected software should adhere to requirements of a particular project. These requirements can be elicited from project management methodologies, and they are used for configuring the selected project management software. However, there are a large number of different project management methodologies and a single software tool is often used to support multiple methodologies. Reconfiguration of PMIS is time-consuming. To address this issue, one could either use a general configuration that fits all methodologies or use a flexible system that can be reconfigured on-demand. However, neither of these approaches is feasible in practice. Therefore, it is proposed to establish a baseline configuration for PMIS what would cover majority of typical project management requirements. The remaining set of requirements specific to each methodology can be configured on-demand.

The objective of this paper is to determine requirements for the baseline configuration of PMIS and to establish a high level definition of the baseline configuration. The baseline configuration is intended to be independent of particular methodologies or software tools. To define the baseline configuration, requirements for PMIS are gathered. The description of these requirements is obtained from $\mathrm{PM}$ and related methodologies such as PMBOK, PRINCE2, RUP, MSF, ITIL, MOF, SCRUM and others. Investigations on PM software options and evaluation are used as a second source of information. All defined requirements can be summarized in the main groups of requirements. The PMIS baseline configuration has been defined using this requirement groups. It describes main elements and processes in PMIS that represents most part of users' needs. Defined baseline configuration further will be used as start-up information in the configuration process of the PMIS [5].

This article is structured as follows. The literature review describes different PM methodologies and research works that are used in generation of the PMIS requirement list. Requirements are divided in groups. The high level description of the baseline configuration of PMIS is defined. Comparison of the baseline configuration with some existing PMIS tools is performed. At the end, some conclusions and future works are given.

\section{Literature Review}

Literature review deals with various PM methodologies and studies on the PMIS options. 


\section{Project Management Methodologies}

Different PM methodologies are developed that describe PM works organization, standards, guidelines and best practices. Some of these methodologies are general and they can use in any area. Domain specific PM methodologies are also available. Along with a general works description, they also include domain specific information and activities.

Some of the known general methodologies are Project Management Body of Knowledge (PMBOK), PRINCE2 and SCRUM.

PMBOK [6] uses nine knowledge areas to describe the PM cycle. Each area is described with management processes that include inputs, tools, techniques and outputs. PM functionality and requirements of PMIS are defined in these management processes. PMBOK is ANSI standard for project management.

Similarly with PMBOK, PM functionality also is described in PRINCE2 [7]. Eight processes, eight components and four techniques are defined in this methodology. Each process consists of sub-processes, which use a certain input and output information.

Compared with the previous two methodologies SCRUM [8] is radically different because it belongs to the agile management approaches. SCRUM is an iterative incremental framework for managing complex work. This methodology commonly is used in software development. SCRUM focuses on the organization of project iterations.

Many domain specific PM methodologies are in the IT area because of a large number of projects conducted in this area [4]. RUP and MSF are methodologies for software development, ITIL and MOF - are methodologies for IT management and governance.

RUP [9] is an iterative software development framework. Four project lifecycle phases and nine disciplines are defined for software development. Two of supporting disciplines are configuration and change management and project management that describe PM activities and functionality. Roles, activities, artefacts, tools are described in a standardized manner.

MSF [10] is described in a similar manner as RUP. MSF team model and governance model are defined. PM process activities are described and, particularly, the risk management. This methodology also defines roles, typical work items, work products and product development workstreams.

ITIL [11] is a set of concepts and policies for managing IT infrastructure, development and operations. ITIL is published in a series of books where a detailed description are given of important IT practices including PM. MOF [12] is a similar methodology that provide guidance across the entire IT life cycle. ITIL and MOF are related with international standard ISO/IEC 20000 that defines a set of IT service management processes.

Research about application of PM standards in Germany and Switzerland has been performed by Ahlemann, Teuteberg and Vogelsang [13]. This research includes description of benefits and problems related to the usage of standards.

All these methodologies have a similar set of main elements, they differ the level of detail, PM process organization, terminology and included PM best practices.

\section{Evaluation of PMIS}

PMIS requirements and evaluation criteria have been formulated in several investigations. Wood [14, 15] has tried to formulate perfect project planning and management tool description, his main emphasis was put on knowledge and templates. Similarly, Filev [16] describes capabilities of ideal PM tool for teamwork collaboration and effective interface including e-mail integration.

PMIS evaluation criteria have been defined by Bryce [17]. These criteria describe requirements of the project life cycle, but neglect such management areas as quality, risk, change and configuration.

Studies about most used project management software functionalities have been performed by Besner and Hobbs [2].

Wider studies of PMIS and their requirements have performed by Ahlemann [18]. He proposes the Mmodel as a base for the requirement description in various management levels and step of project life cycle. Requirements of all PM knowledge areas have included in this model. The M-model has been supplemented with conceptual reference model RefModPM [19], which can be used for requirement specification and commercial software selection. Liu, Zhao, Sun and Yin [20] have been developed an approach for PMIS requirement analysis. Both of these investigations have been directed to specific situations PM analyse and requirement generation.

PMIS configuration descriptions have been also designed, but they are basically intended for particular tools, such as SAP [21].

All reviewed research works PMIS requirements have been described informally or focus on a specific tool. Exception is Ahlemann M-Model that includes main requirements.

\section{PMIS Requirement Groups}

In order to identify requirements for PMIS, analysis of existing information sources is performed. Seven project management methodologies (PMBOK, PRINCE2, SCRUM, RUP, MSF, ITIL and MOF) and 
four works on evaluation of PM software tools (Wood, Filev, Bryce, Ahlemann) have been analyzed. Requirements are divided in 15 groups. Table 1 shows all these groups and general descriptions for each group. During the analysis, it is determined whether a particular methodology or research work considers.

Description of PMIS requirement groups

\begin{tabular}{|c|c|}
\hline Group & General requirement description \\
\hline $\begin{array}{l}\text { A. Project } \\
\text { planning }\end{array}$ & $\begin{array}{l}\text { Implement the planning, estimating, scheduling, budgeting and analysis methods. Generate work } \\
\text { breakdown structure (WBS) and deliverables, activity and milestone lists, baseline for scope, schedule } \\
\text { and cost, schedule model and project budget. Graphically presentation and diagramming. Generate } \\
\text { and accept planning documentation. Implement resource allocation. Define project metrics. }\end{array}$ \\
\hline $\begin{array}{l}\text { B. Project } \\
\text { control }\end{array}$ & $\begin{array}{l}\text { Implement earned value techniques, variance analysis, forecasting, comparison of actual project } \\
\text { performance against the project management plan, scope inspection and deliverable acceptance. } \\
\text { Generate graphical measurements presentation and project records. }\end{array}$ \\
\hline C. Resource & $\begin{array}{l}\text { Define resource breakdown structure (RBS), organization chart, project roles, responsibilities, skills, } \\
\text { reporting relationships, authority and competences. Generate resource availability, calendar, and cost } \\
\text { rate. Generate staff management plan. Implement conflict management. }\end{array}$ \\
\hline $\begin{array}{l}\text { D. Quality } \\
\text { management }\end{array}$ & $\begin{array}{l}\text { Define quality management plan, quality metrics, checklist and baseline. Implement quality } \\
\text { management system, quality planning techniques and tools, quality audit, quality control/review } \\
\text { techniques and procedures. Generate quality documentation, quality log and quality report. Define, } \\
\text { measure and test acceptance criteria. }\end{array}$ \\
\hline $\begin{array}{c}\text { E. Risks } \\
\text { management }\end{array}$ & $\begin{array}{l}\text { Define risk management plan, risk breakdown structure and categories, risk metrics, risk trigger } \\
\text { events and response process. Generate risk register, risk log and risk status report. Implement risk } \\
\text { identification, analyze, prioritizing, modelling, estimating techniques, risk monitoring and audit. }\end{array}$ \\
\hline $\begin{array}{l}\text { F. Change } \\
\text { management }\end{array}$ & $\begin{array}{l}\text { Define change control system, issue types, workflows and processes. Generate request for change, } \\
\text { issues, problems, defects, errors and bugs. Implement change analyse, prioritize, evaluation, } \\
\text { acceptance, estimating, integration in schedule. Monitor, track and document change. }\end{array}$ \\
\hline $\begin{array}{c}\text { G. } \\
\text { Communication }\end{array}$ & $\begin{array}{l}\text { Define communication plan, internal and external communication channels and communication } \\
\text { requirements. Implement stakeholder analyse, information gathering, retrieval and distribution } \\
\text { technology, tools and methods. Generate project reports and presentations, communication records } \\
\text { and documentation. Implement presentation tools. Meetings. }\end{array}$ \\
\hline H. Reporting & $\begin{array}{l}\text { Implement time and cost reporting system. Generate work performance information, progress } \\
\text { measurements, forecasts, reports and reviews. }\end{array}$ \\
\hline I. Procurement & $\begin{array}{l}\text { Generate project plan, statement, procurement documents, evaluation criteria, contract, contract } \\
\text { documentation and contract performance report. Implement seller selection methods, payment system } \\
\text { and claim administration Monitor, control and document contract performance. }\end{array}$ \\
\hline $\begin{array}{l}\text { J. Configuration } \\
\text { management }\end{array}$ & $\begin{array}{l}\text { Implement document and file management system that includes storage, versioning, classification and } \\
\text { searching and configuration management system. Generate, track, update, and document } \\
\text { configuration item records. Perform and document configuration audit. }\end{array}$ \\
\hline $\begin{array}{l}\text { K. Management } \\
\text { documents }\end{array}$ & Define PM documents, its structure. \\
\hline $\begin{array}{l}\text { L. Project } \\
\text { processes }\end{array}$ & e and execute different project management processes (workflows). \\
\hline M. Initiative & $\begin{array}{l}\text { Define project environment, assumptions and constraints. Implement idea generation and } \\
\text { classification, project appraisal and selection methods. }\end{array}$ \\
\hline $\begin{array}{l}\text { N. Project } \\
\text { knowledge }\end{array}$ & $\begin{array}{l}\text { Implement project management knowledge base, templates and guidelines. Document, categorizing } \\
\text { and storing of project records and lessons learned. Search in knowledge database. Implement adequate } \\
\text { knowledge representation in project life-cycle. }\end{array}$ \\
\hline $\begin{array}{l}\text { O. Team } \\
\text { collaboration } \\
\text { and personal } \\
\text { information }\end{array}$ & $\begin{array}{l}\text { Define virtual team. Share project information and documentation. Implement dashboard, } \\
\text { personalized start screen, contact management, personal calendars, chatting, notifications and alerts. } \\
\text { Generate actual activities list for project and for each team member. }\end{array}$ \\
\hline
\end{tabular}


Project planning, monitoring, control, resource management, change management, communication, reporting, processes and knowledge have been described in all sources. Quality, configuration management and team collaboration have been mentioned in six methodologies and Ahlemann works Risks management has not been described only in SCRUM and Bryce evaluation checklist. Procurement has been described in PMBOK, MSF, ITIL methodology and researches of Wood and Ahlemann. Management documents have been mentioned only in the methodologies. Initiative has been mentioned in PMBOK and PRINCE2 and it has been elaborated in more detailed manner by Ahlemann.

From the reviewed PM methodologies almost all have requirements in each of the groups. Discrepancy in the terminology used has been observed. Consequently, an additional requirement for PMIS is to ensure terminology according to the selected methodology.

\section{Baseline Configuration of PMIS}

The baseline configuration description includes elements, workflows, fields, default values and business rules. PMIS baseline configuration description definition process has realized as one by one iterative executing the following steps:

1. definition of PMIS use cases using PMIS requirement groups;

2. definition of configuration elements and their related concepts in the PM concept model;

3. definition of configuration elements workflows;

4. description of elements concepts or table fields, default values and business rule.

Structure of the PMIS baseline configuration is outlined by the groups of collected main requirement (Table 1). High-level PMIS elements can be represented using the use case diagram (Fig.1). PMIS configuration can be viewed from two points of view: management and project team member. Project team members mainly interests only it current information and elementary interface to operation perform. Project manager interests all project current information, planning, monitoring and control activities and control that project team properly and timely report information.

For further use case (Fig. 1) detail the PM concept model [22] is used to describe next level elements. The concept model describes PM area concepts and their relationships. It is represented as a UML class diagram.

The result of use case splitting in elements is shown in Table 2. One use case may have one or more elements. Similarly one element can be described with one or more PM concepts. For example, elements metrics, baseline, and stakeholder have only one concept with the same name, but performance review includes such concepts: earned value, variance and forecast.

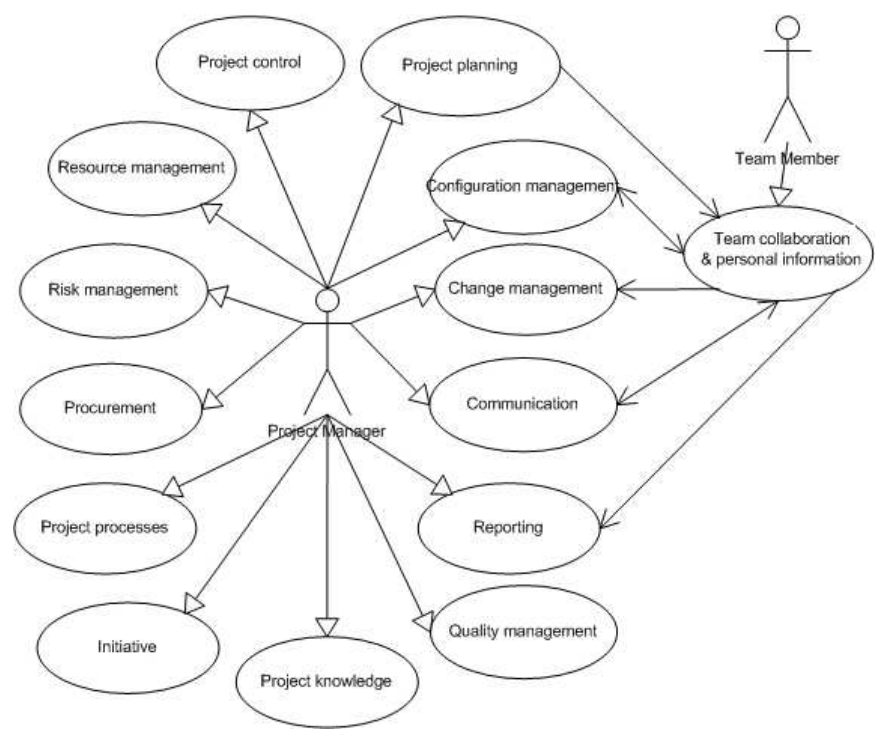

Fig.1. Use case diagram of the PMIS baseline configuration

The next step is workflow definition for elements. Main activities and status of element is described in these workflows. Element may be described with one workflow or with more subordinated and interrelated workflows.

Description of the change management use case is given as an example. Two types of changes are defined: requests for change and issues. Requested changes are defined with concepts change management, requested changes, change, change process. Issue are defined with concepts issue management, issues, issue log, issue process. Both of these types have performed following workflow steps: create, accept, analyze, approve, plan, perform, validate and close (Fig. 2).

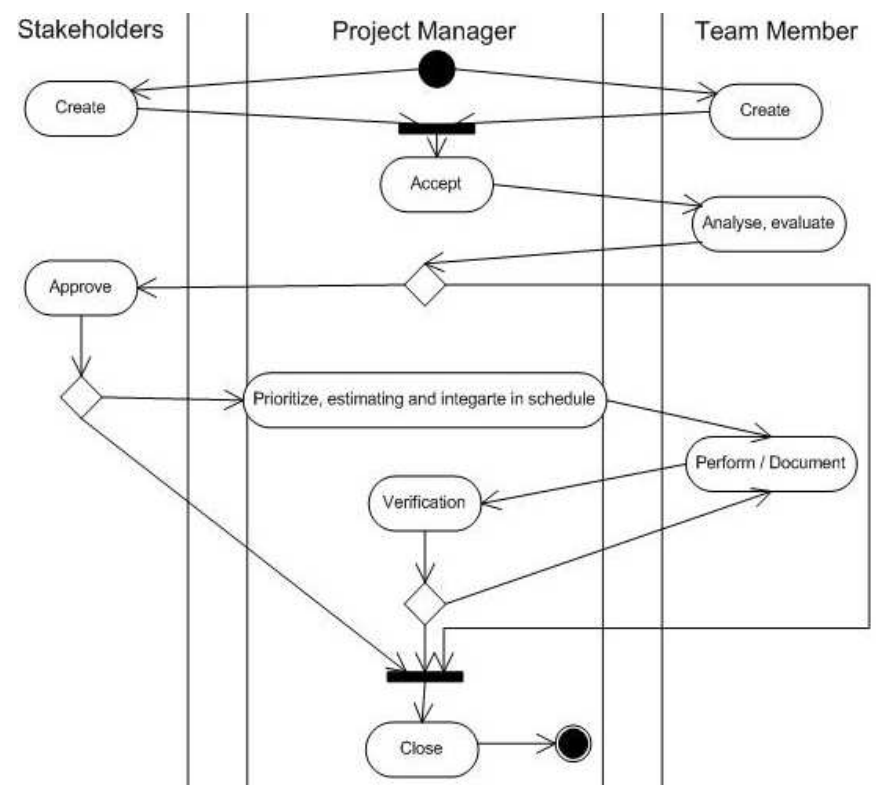

Fig.2. Baseline activities in change management 
Table 2

PMIS baseline configuration use case elements

\begin{tabular}{|l|l|}
\hline \multicolumn{1}{|c|}{ Use case } & \multicolumn{1}{c|}{ Elements } \\
\hline A. Project planning & A1. WBS (+deliverables) \\
& A2. Activity list (+cost) \\
& A3. Budget \\
& A4. Schedule \\
& A5. Metrics/Checklists \\
& A6. Baseline \\
\hline B. Project control & B1. Performance review \\
\hline C. Resource & C1. Role list \\
& C2. Resources \\
& C3. Organization char \\
\hline D. Quality management & D1. Quality assurance \\
\hline E. Risks management & E1. Risk register \\
\hline F. Change management & F1. Requests for change \\
& F2. Issues \\
\hline G. Communication & G1. Stakeholder list \\
& G2. Project reports \\
& G3. Meetings \\
\hline H. Reporting & H1. Time reports \\
& H2. Measurements \\
\hline I. Procurement & H3. Reviews \\
\hline J. Configuration management & I1. Contract list \\
& J1. Configuration item list \\
& J2. File management \\
\hline K. Management document & system \\
\hline L. Project processes & L1. Document/plan list \\
\hline M. Initiative & M1. Environment factor list \\
\hline N. Project knowledge & N1. Templates \\
& N2. Lesson learned \\
\hline O. Team collaboration and & N3. Record databases \\
personal information & O1. Calendar \\
& O2. Actual work list \\
& O3. Notification \\
O4. Chat/Blog \\
\hline & \\
\hline
\end{tabular}

\section{Cross-Examination of the Baseline Configuration}

The baseline configuration should be supported by all PMIS, which aim to provide a full PM functionality. In this example it is evaluated how the baseline configuration of PMIS is supported by three software tools: Microsoft Project Server, SAP Project System and Planisware. This comparison describes what elements from Table 2 are supported by the selected software tool.

Microsoft Project Server [23] is developed by Microsoft, the latest version is 2007. MS Project Server supported configuration elements are shown in Table 3. The missing elements can be ensured by the Microsoft extensible and programming tools. Some other features are OLAP possibilities, Outlook and other Office tools integration, Project Guide and others.

SAP R/3 is one of the most powerful enterprise solution produced by SAP AG. One of the SAP modules is Project System (PS) [21] that supports internal projects. PS supported configuration elements are shown in Table 3. PS includes powerful techniques for management of resources and costs.

Planisware 5 (also known as OPX2) [24] is enterprise project portfolio management software developed by Planisware. Planisware supported configuration elements are shown in Table 3. Some other features are program management and integration with Office tools.

Table 3

PMIS supported configuration elements

\begin{tabular}{|l|c|c|c|}
\hline \multicolumn{1}{|c|}{ Elements } & $\begin{array}{c}\text { MS } \\
\text { Project } \\
\text { Server }\end{array}$ & $\begin{array}{c}\text { SAP } \\
\text { Project } \\
\text { System }\end{array}$ & $\begin{array}{c}\text { Planis } \\
\text { ware }\end{array}$ \\
\hline A1. WBS (+deliverables) & + & + & + \\
\hline A2. Activity list (+cost) & + & + & + \\
\hline A3. Budget & + & + & + \\
\hline A4. Schedule & + & + & + \\
\hline A5. Metrics/Checklists & - & + & - \\
\hline A6. Baseline & + & - & + \\
\hline B1. Performance review & + & + & + \\
\hline C1. Role list & + & + & - \\
\hline C2. Resources & + & + & + \\
\hline C3. Organization char & - & + & - \\
\hline D1. Quality assurance & - & - & - \\
\hline E1. Risk register & + & - & + \\
\hline F1. Request for change & + & - & + \\
\hline F2. Issues & + & - & + \\
\hline G1. Stakeholder list & - & - & - \\
\hline G2. Project reports & + & + & + \\
\hline G3. Meetings & + & + & - \\
\hline H1. Time report & + & + & + \\
\hline H2. Measurements & + & + & + \\
\hline H3. Reviews & - & - & - \\
\hline I1. Contract list & + & + & + \\
\hline J1. Configuration item list & - & - & - \\
\hline J2. File management & + & + & + \\
\hline system & + & - & - \\
\hline K1. Document/Plan list & - & - & + \\
\hline L2. Process list & + & + & + \\
\hline M1. Environment factors & - & - & - \\
\hline N1. Templates & + & + & + \\
\hline N2. Lesson learned & - & - & - \\
\hline N3. Record database & - & - & - \\
\hline N4. Searches & + & - & + \\
\hline O1. Calendar & + & - & + \\
\hline O2. Actual work list & + & + \\
\hline O3. Notification & + & + \\
\hline O4. Chat/Blog & + & + \\
\hline
\end{tabular}


As it can be observed, the reviewed PMIS have no problems with support of the project management basic functionality such as planning, control, resources, reporting, procurement, document versioning and standard processes. However, there are limitations to deal with quality area elements, configuration management and use of knowledge.

\section{Conclusions and Future Work}

The article described definition of the baseline configuration of PMIS. This process consists of four parts: literature review and requirement list generation, requirement grouping, baseline configuration definition and it comparison with PMIS possibilities. During the literature review requirements have collected from seven methodologies and four research works. All requirements have been gathered together in 15 groups, which are also used as use cases of the baseline configuration of PMIS. Requirements and PM concept model have been used for definition of elements to each use case. Workflows have been defined for each element. As the result, a high-level description of the baseline configuration has been defined. To clarify capabilities of existing software tools for implementation of the baseline configuration, the crossexamination of the baseline configuration and three PMIS has been carried out.

The description of the baseline configuration of PMIS given in the article is initial and general. Further detail is required including detailed description of elements and workflows and definition of fields, default values and business rules. Hence, detailed comparison of the baseline configuration and PMIS capabilities is needed.

Baseline configuration testing will be performed in two stages. At first, some PMIS will be configured according baseline. The second project managers will be introduced to the baseline configuration and asked to assess it.

Defined baseline configuration of PMIS further will be used in configuration process of the PMIS [5].

\section{Acknowledgements}

The author would like to acknowledge Dr.sc.ing. Jānis Grabis for his scientific guidance and support.

This article has been supported by the European Social Fund within the project „Support for the implementation of doctoral studies at Riga Technical University".

\section{References}

1. White D., Fortune J. Current practice in project management - an empirical study. International Journal of Project Management. - Nr. 20 (2002), 1. 11.

2.Besner C., Hobbs B. An Empirical Investigation of Project Management Practice A Summary of the Survey Results: PMI - URL: http://www.pmi.org/PDF/pp_besnerhobbs.pdf - Visit date September 2009.

3.Global Project Management Survey- URL: http://www.pmportal.co.uk/uploads/documents/PIPC Survey.pdf- Visit date November 2009.

4. Raymond L., Bergeron F. Project management information systems: An empirical study of their impact on project managers and project success. International Journal of Project Management. - Nr. 26 (2008), 213. - 220.

5.Bērziša S., Grabis J. An Approach for Implementation of Project Management Information Systems. Information Systems Development: toward of Services Provision Society, 2008. August. NewYork: Springer-Verlag, 2009, 423. - 431. p.

6.Project Management Institute. Guide to the Project Management Body of Knowledge (PMBOK) Fourth edition. - Newtown Square: PMI Publications, 2008, $496 \mathrm{p}$.

7. Hedeman B., Heemst G.V.van, Fredriksz H. Project Management Based on PRINCE2 - PRINCE2 Edition 2005. - Zaltbommel: Van Haren Publishing, 2007, 250.p.

8. Schwaber K. Agile Project Management with SCRUM. - Washington: Microsoft Press, 2004, 163 p.

9.Kruchten P. The Rational Unified Process: an introduction Third edition. - Boston: AddisonWesley, 2004, 300.p.

10. Turner M.S.V. Microsoft Solutions Framework Essentials: Building Successful Technology Solution. - Washington: Microsoft Press, 2006, 310 p.

11. ITIL Open Guide. URL: http://www.itlibrary.org/ Visit date September 2009.

12. Microsoft Operations Framework: Microsoft TechNet - URL: http://technet.microsoft.com/enus/solutionaccelerators/dd320379.aspx - Visit date September 2009.

13. Ahlemann F., Teuteberg F., Vogelsang K. Project management standards - Diffusion and application in Germany and Switzerland. International Journal of Project Management. - Nr. 27 (2009), 292. - 303.

14. Software Search: Gantthead.com - URL: http://www.gantthead.com/content/articles/218140.cf $\underline{\text { m }}$ - Visit date September 2009. 
15. Software Search (Part 2): Gantthead.com - URL: http://www.gantthead.com/content/articles/220423.cf m - Visit date September 2009.

16. What Would An Ideal Project Management Tool Look Like? $\quad$ BNET - URL: http://jobfunctions.bnet.com/abstract.aspx?docid $=950$ $\underline{609}$ - Visit date September 2009

17. Project Management System Evaluation Checklist: ProjectSmart

URL:

http://www.projectsmart.co.uk/project-management-

system-evaluation-checklist.html - Visit date

September 2009.

18. Ahlemann F. Project management Software Systems - Requirements, Selection Processes and Products, $5^{\text {th }}$ edition. - Wurzburg: BARC, 2008, 470 p.

19. Ahlemann F. Towards a conceptual reference model of project management information systems. International Journal of Project Management. - Nr. 27 (2009), 19. - 30.

20. Liu W., Zhao S., Sun Y., Yin M. An Approach to Project Management Information System Requirements analysis. International Conference on Intelligent Computation Technology and Automation, 2008. October. - NewYork: IEEE Computer Society, 2008, 957.-961. (Volume 2)

21. Dowling K.N. SAP Project System Handbook. NewYork: Mc Graw Hill, 2008, 298 p.

22. Bērziša S., Towards an XML Schema for Configuration of Project Management Information Systems: Conceptual Modelling. $-13^{\text {th }}$ East-European Conference on Advances in Databases and Information Systems, 2009. September. - NewYork: Springer, 2009 (In Press).

23. Microsoft office project server 2007: Microsoft URL: $\quad$ http://office.microsoft.com/enus/projectserver/FX100739841033.aspx - Visit date September 2009.

24. Planisware Capabilities: Planisware - URL: http://www.planisware.com/main.php?docid=11506 - Visit date September 2009.

Solvita Bērziša. Projektu vadības informācijas sistēmas pamata konfigurācija

Projektu vadības informācijas sistēmas mērķis ir atbalstît projekta izstrādi un vadību, kā arī nodrošināt operatīvu projekta informāciju. Ieviešot projektu vadības informācijas sistēmu, to ir nepieciešams sakonfigurēt atbilstoši projektu vadības prasībām. Lai atvieglotu šo uzdevumu, kā konfigurācijas procesa sākuma punktu var izmantot pamata konfigurāciju. Līdz ar to raksta mērķis ir noteikt projektu vadības informācijas sistēmas pamata konfigurāciju. Pamata konfigurācija ir izstrādāta saskaṇā ar tipisko projektu vadības prasību kopu.

Prasības ir noskaidrotas, apkopojot vairākas projektu vadības metodologijas un pētījumus par projektu vadības informācijas sistēmu novērtēšanu. Šìs prasīibas ir sadalītas 15 grupās. Izmantojot prasības, augsta līmeņa projektu vadības informācijas sistēmas pamata konfigurācijas apraksts ir definēts. Tas sastāv no tipisku projektu vadības scenāriju un darbplūsmu saraksta kā arī no attiecīgo konceptu, to noklusēto vērtību un biznesa likumu saraksta. Bāzes konfigurācija ir salīdzināta ar dažu izvēlētu projektu vadības informācijas sistēmu konfigurācijām. Iegūtie rezultāti tālāk tiks izmantoti projektu vadības informācijas sistēmas konfigurācijas procesā.

Солвита Берзиша. Базовая конфигурация информационной системы управления проектами

Цель разработки информационных систем управления проектами - упростить разработку и управление проектами, а так же предоставлять оперативную проектную информацию. Информационная система управления проектами должна быть настроена в соответствии с требованиями управления проектами еще на стадии разработки системы. Для облегчения этой задачи, в качестве отправной точки процесса настройки может быть использована единая базовая конфигурация. Цель данной статьи - определить базовую конфигурацию информационной системы управления проектами. Базовая конфигурация разработана в соответствии с типовыми требованиями управления проектами.

Вышеупомянутые требования были определены, суммируя ряд выбранных методологий управления проектами и исследований по оценке информационных систем управления проектами. Требования разделены на 15 групп. На основе этих требований определено описание базовой конфигурации информационной системы управления проектами. Оно состоит из перечня типовых сценариев по управлению проектом, перечня технологических процессов, а так же списка соответствующих определений, их значений по умолчанию и бизнес-правил. Проведено сравнение предлагаемой базовой конфигурации с конфигурациями, используемыми в выбранных информационных системах управления проектами. Полученные результаты в дальнейшем могут быть использованы в процессе конфигурации информационных систем управления проектами. 